\title{
Embeddedness and cohesion: regimes of urban public goods distribution
}

\author{
Benjamin H. Bradlow ${ }^{1}$ (iD
}

Accepted: 18 June 2021/Published online: 10 July 2021

(C) The Author(s), under exclusive licence to Springer Nature B.V. 2021

\begin{abstract}
Why do some urban governing regimes realize a more equal distribution of public goods than others? Local government interventions in São Paulo, Brazil, have produced surprisingly effective redistribution of residential public goods - housing and sanitation - between 1989 and 2016. I use original interviews and archival research for a comparative-historical analysis of variation across time in São Paulo’s governance of housing and sanitation. I argue that sequential configurations of a) "embeddedness" of the local state in civil society and b) the "cohesion" of the institutional sphere of the local state, explain why and when urban governing regimes generate the coordinating capacity to distribute public goods on a programmatic basis. I further illustrate how these configurations can explain variation in urban governing regimes across the world.
\end{abstract}

Keywords Bureaucracy $\cdot$ Governance $\cdot$ Housing $\cdot$ Movements $\cdot$ Sanitation $\cdot$ Urban inequality

From a "new urban crisis" (Florida, 2017) in the United States, to a "planet of slums" (Davis, 2006) across the globe, unequal access to public goods pervades urban life. The scholarly tendency has been to explain urban exclusions as determined by the structural role of cities in the globalized integration of markets (Brenner \& Theodore, 2002). Even so, democracy creates the possibility for alternative distributions of social power to address inequalities (Usmani, 2018). Explaining the distribution of public goods in democratic cities begs for variation-finding approaches. Why do some urban governing regimes realize a more equal distribution of public goods than others?

This article proposes conceptual tools for answering this question through a comparative and historical study of a "least likely case" (Gerring, 2005) for improvements in including previously excluded residents into the built environment of public goods in the city. São Paulo, Brazil, the fourteenth most populous city in the world, grew

Benjamin H. Bradlow

bhbradlow@fas.harvard.edu

1 Weatherhead Center for International Affairs, Harvard University, Cambridge, MA, USA 
exponentially under a military dictatorship from the late 1960s to mid-1980s. The city's sprawling shacklands, originally constructed out of wood, and often without electricity, water, sanitation or paved roads, became iconic as examples of extreme exclusion from the formal built environment. Such marginalization was accompanied by an oligarchical form of local government that literally erased many favelas ${ }^{1}$ from official maps (Holston, 2008). But between the passage of a newly democratic federal constitution in 1988 and 2016, the local state made remarkable improvements in the inclusion of poor, peripheral neighborhoods in the physical infrastructures of livability in the city.

The unexpected redistributive outcomes that characterize the case and the variation that I find across time within the case make it possible to generate new hypotheses for explaining when and why local governments can more effectively distribute urban public goods. Theories of urban political economy mostly highlight the dominance of actors who access returns to high-value land in urban politics, thereby deepening inequalities in the distribution of public goods (Logan \& Molotch, 1987; Stone, 1989). In contrast, studies on the emergence of social welfare and developmental states have focused on explaining national-level variation in distributional outcomes (EspingAndersen, 1990; Rueschemeyer et al., 1992). These explanations tend to downplay the role of social movements outside of organized labor and focused on dynamics of party politics and state organization. Studies of social movements generally focus on the mechanisms through which movements affect the political will of states, but they assume state capacity to realize the political will formed through movement action (Amenta et al., 2010).

I find that both movements and internal state dynamics matter for explaining the distribution of public goods in cities. Social movements for housing, "embed" the state in civil society, which in turn generates "cohesion" of the bureaucratic sphere. This makes it possible to deliver a more programmatic, inclusive distribution of public goods across multiple policy areas.

"Embeddedness" is defined by the connections of state actors and institutions to associations and movements in civil society. The term recalls work on the relationship of national economic development agencies to business elites (Evans, 1995). My approach adapts the term to the local level to describe the network ties between bureaucrats and movement activists that make policy changes responsive to programmatic demands of movements. We observe "embeddedness" when bureaucrats across the hierarchy of an agency - from "street-level" bureaucrats to agency directors regularly interact with movements demanding things that are supposed to be working on. Furthermore, movement activists may also work directly within bureaucratic agencies.

"Cohesion" is defined by the coordinating capacity of local state institutions to implement policies across two dimensions: "horizontal", meaning across line agencies at the municipal scale, and "vertical", meaning across scales of government (ie. federal, state, municipal). "Cohesion" is a characteristic of state capacity necessary for delivering goods that require coordinated bureaucratic action of multiple agencies through a multi-scalar framework of funding and regulation. We can identify this characteristic through policies, reforms, and circulation of bureaucrats that directly address the coordination of delivery of public goods.

\footnotetext{
${ }^{1}$ The Portuguese term for informal settlements.
} 
Configurations of "embeddedness" and "cohesion" can vary across cities. Within cities they can change over time through causal sequences. Politicians and bureaucrats face the constraints of inherited urban administrative apparatuses, as well as the organizational forms, capacities and demands of civil society. These are shaped by prior political dynamics and policies.

The empirical analysis in this paper focuses on exploiting within-case variation over time to explain the sequence of configurations of "embeddedness" and "cohesion" in São Paulo. I do so through a historical analysis of the policy spheres of housing and sanitation, in which I classify a sequence of four different municipal "regimes" of embeddedness and cohesion after Brazil's transition to democracy in the mid-1980s. This transition was punctuated by a new Federal Constitution in 1988 that decentralized governing authority to municipalities, promoted fiscal transfers to the municipal scale, and included new rights to public goods like housing and sanitation. The study ends in 2016, when Brazil entered a new political cycle after the impeachment of its president, Dilma Rousseff, and subsequent municipal elections.

São Paulo is not a radical reversal of a global paradigm of urban development that prioritizes growth over redistribution. Private property and powerful propertied interests remain dominant. Even so, social mobilization in the city after democratization enabled a project of local state building that has produced significant inclusion in the distribution of urban public goods.

My empirical argument about the São Paulo case is that social movements for housing have generated power within the local state to countervail the real estate interests that have dominated the distributive ends of the city's governance. The "embeddedness" of the local state in housing movements generated a dense web of interpersonal ties between bureaucrats and activists that could transmit political will and trust for implementing policies, often jointly, to improve housing and sanitation services in the city's poor peripheries. In turn, this "embeddedness" produced a multidimensional coordinating capacity within the local state — "cohesion" - that traversed political party lines to implement plans and give redistributive policies staying power. Over time, this strengthened local state capacity to deliver a more inclusive distribution of public goods.

\section{The case of São Paulo}

The link between authoritarian governance and residential exclusion has been the historic hallmark of life in São Paulo. ${ }^{2}$ As the city began growing in the middle of the twentieth century, so did informal settlements and active policies of eviction from the formal city. During a civilian dictatorship in the 1940s, an estimated 10-15\% of the city's inhabitants were evicted from their homes, in direct contradiction of existing legal protections for tenants, which accounted for two-thirds of residents at that time (Bonduki, 1994). Under Brazil's military dictatorship, from the late 1960s to mid 1980s, São Paulo underwent one of the largest explosions of urbanization anywhere in the world. The city's population grew from 3.8 million people in 1960 to 9.6 million in 1990.

\footnotetext{
${ }^{2}$ Race and class are closely correlated in settlement patterns and access to public goods in São Paulo (see França, 2015).
} 
The twin processes of urbanization and exclusion defined the city's harsh inequalities. $^{3}$ The largely unrecognized, unmapped and unincorporated sectors of the urban population, clustered in residential informal slums, were on one side of a sharply segregated barrier to citizenship. The stark rationing of public goods between a wealthy core and sprawling peripheral neighborhoods became a defining feature of the spatial organization of life in the city. In 1968, $41.3 \%$ of all households in the city of São Paulo were without a sewage connection (Camargo et al., 1976). The proportion of residents living in favelas grew more than seven-fold, from 1.1\% in 1973 towards the beginning of the dictatorship to $7.7 \%$ by the end in 1987 (Rolnick, Kowarick and Somekh 1991). Generally lacking basic services such as electricity, water, and sanitation, these neighborhoods were marked by a form of development entirely outside of the ambit of any formal planning authority, often referred to as auto-construção, or self-build. Many other parts of the city housed the urban poor in areas with only limited services (Holston, 2008).

Brazil's transition to democracy in the mid-1980s culminated in a new federal constitution in 1988 and the first direct presidential elections in 1989. This produced possibilities for urban governance with unprecedented degrees of local autonomy and accountability in the provision of basic services. A centralized mode of municipal governance, with mayors appointed by federal authorities, gave way to direct elections of executive mayors.

As São Paulo experienced a rapid opening of power, the city's labor structure underwent a shift often associated with deepening exclusion across the globe. Home to 12 million residents today, São Paulo is the financial center of Brazil and Latin America. The city and its surrounding metropolitan region comprised the industrial epicenter of the Brazilian economic development "miracle" of the 1970s and 1980s. The city has made a decisive shift over the past 40 years in prioritizing functions critical to the integration of Brazil into global markets, especially finance, insurance, and real estate (Fix, 2007). São Paulo has seen the steepest drop in manufacturing as a share of total employment of all major Brazilian cities, with a rise in employment in services. In $1977,42 \%$ of jobs in the São Paulo metropolitan region were in manufacturing. In 2009 , the share of jobs in manufacturing was cut almost in half to $22 \%$ (Biderman \& Lopes, 2015).

Since the ratification of the Federal Constitution in 1988, the standard of living in São Paulo has improved substantially with respect to the distribution of public goods. The Constitution decentralized the responsibility for distributing residential public goods, and stipulated financial transfers to municipalities to fulfill these responsibilities (Arretche, 1999). While Brazil has generally improved along a wide range of social development indicators during this period, this process has been marked by significant subnational variation across cities (Gibson, 2018).

While the share of the total households in São Paulo located in informal settlements has grown from $9.2 \%$ in 1991 to $11.6 \%$ in 2010 , access to sanitation in informal settlements has almost tripled from $25.1 \%$ in 1991 to $67.9 \%$ in 2010 (Marques \&

\footnotetext{
$\overline{3}$ A "São Paulo School" of urban sociology, which has gone untranslated in English, emerged in the 1970s as Brazilian researchers began to document dimensions of extreme segregation and differentiation in the city The titles of prominent works from this period tell the tale: "Critique of Dualist Reason" (de Oliveira, 1972), "São Paulo: Growth and Poverty" (Camargo et al., 1976) and "Urban Plunder" (Kowarick, 1980).
} 
Saraiva, 2017). In essence, while a shortage in formal housing persists and has even grown slightly, the difference in overall neighborhood quality of life has narrowed significantly. Furthermore, recent work has found shifts in residential settlement patterns that do not comport with the historic reality of core-peripheral spatial organization of wealthy and poor areas in the city. These studies highlight a decline in classbased residential segregation in São Paulo (Marques, 2015). There is now a more even distribution of basic services across both poor and rich neighborhoods (Marques, 2014). Drawing on these academic studies and similar findings by a state level public agency in São Paulo, Caldeira (2017) describes this shift as being one from a "homogenous and vast periphery" to "a city that is a kind of patchwork." The defining inequality of a wealthy core and poor periphery has transformed into a heterogeneous geography of difference, with pockets of relative wealth and poverty closer together, spread throughout the city. The effect is a city-wide change in conditions in the built environment, as opposed to limited, neighborhood-specific change.

\section{São Paulo in comparative perspective}

How can we interpret the significance of these outcomes in São Paulo? I illustrate this through both a within-country comparison and a cross-country comparison to cities where we would expect similar outcomes. The former controls for country-level, as well as sub-national factors, while the later approach controls for similar national political trajectories.

A brief comparison with Rio de Janeiro, Brazil's second largest city ${ }^{4}$ and, like São Paulo, in the southeast of the country, highlights two critical differences. First, while the vulnerability associated with informality in São Paulo has been reduced, it has increased in Rio de Janeiro. Caldeira (2017) finds that collective evictions are increasingly rare in São Paulo and that on-site slum improvements have become the governing norm. We see the opposite trajectory in Rio de Janeiro. A prior focus on slum upgrading projects has given way to more frequent evictions, especially through planning processes for multiple global "mega-events" of the World Cup and Olympics hosted in 2014 and 2016 (Becerril, 2017). The share of households in the city living in informal settlements is more than double that in São Paulo (IBGE).

Second, Rio de Janeiro's local government is increasingly unable to generate and implement policies that limit the role of the private market so that it can improve conditions of below-market rate housing for poor residents. São Paulo was the first major city in Brazil to develop a legal framework to circumscribe the role of the private sector in extracting value from property investment in order to reserve well-located areas for social housing. These legal instruments were developed in two consecutive master plans, in 2002 and 2014, and have been the basis for expropriating private properties for municipal social housing projects. In contrast, Rio de Janeiro has suffered from frequent critiques that its master plans have not had effective legal mechanisms for meaningful implementation (Otávio, 2019).

\footnotetext{
${ }^{4}$ Along with the city of Belém, these cities account for over $43.7 \%$ of all precarious housing in the country (Rocco et al., 2019)
} 
Another way of putting São Paulo in perspective is to compare to cities where we might expect to see similar outcomes due to similar national political trajectories. South Africa is a case that has previously generated analogous redistributive expectations due to its political and institutional similarities after transition to democracy (Seidman, 1994). South Africa's largest city, Johannesburg, is a useful comparison because it has had a similar proportion of residents living informal settlements. ${ }^{5}$ In São Paulo, access to sanitation in informal settlements has almost tripled from $25.1 \%$ in 1991 to $67.9 \%$ in 2010. In Johannesburg, the percentage of households in informal settlements with access to a flush toilet went from 36\% in 1996 to $47 \%$ in 2011 (StatsSA). Evictions are frequent (Clarno, 2017) and the spatial distribution of settlement patterns largely reproduces the segregated characteristics of the Apartheid era (Krack Selzer \& Heller, 2010).

The methodological and analytical concern here is to explain why there have been sustained periods of local government capacity to generate a more equal distribution of public goods. The variation between São Paulo and other seemingly similar cases supports the contention that we need to look to local governance dynamics to explain these material outcomes.

\section{Why is urban redistribution so hard?}

Literatures in urban sociology and the sociology of development propose hypotheses about a case like São Paulo which do not match the trajectory of the city's distribution of residential public goods (see Fig. 1). While the urban literature emphasizes the structuring role of globalization and power of business elites, the strain of "powerresources" theory in the development literature emphasizes variation, but within a national political framework. That local institutions are subject to contingency and variation is relatively underplayed in these accounts.

To be sure, the literature on urban neoliberalism emphasizes that politics and institutions matter and can vary (Brenner \& Theodore, 2002). However, the emphasis on the structural shift towards neoliberalism constrains agency at the local level. This structural logic is at work in more locally-driven theories. "Growth machine" theory (Logan \& Molotch, 1987) has focused on local coalitions between business and political elites to maximize economic growth as the decisive relationship in urban political economy. The collective capacities of a "regime" in "urban regime theory" are defined by the interaction between the configuration of actors with the capability to act and the policies that are the object of institutional action (Stone, 1989). These approaches align with the more global view of urban restructuring because of the propensity of local authorities to ally with business elites to respond to the competitive pressures of neoliberal sub-national reforms.

The tools of "growth machine" and "regime" theorists are useful for identifying both the importance of local institutional configurations, and the varieties of conflict between growth-oriented and redistributive policy goals. Stone (1993) theorized the possibility of two types of redistribution-oriented regimes, which he describes as

\footnotetext{
${ }^{5}$ Between 10 and $15 \%$ of all households across the three censuses taken since South Africa's transition to democracy in 1994 (Stats SA).
} 


\begin{tabular}{|c|c|c|}
\hline theory & prediction & confounding issue/s \\
\hline growth coalitions / regimes & $\begin{array}{c}\text { growing inequality due to } \\
\text { power of local } \\
\text { development elites in } \\
\text { coalition with local state }\end{array}$ & $\begin{array}{c}\text { São Paulo has achieved } \\
\text { redistributive gains in } \\
\text { standard of living }\end{array}$ \\
\hline $\begin{array}{c}\text { power-resources / class } \\
\text { coalitions }\end{array}$ & $\begin{array}{c}\text { redistributive if aligned to } \\
\text { a programmatic party of } \\
\text { the left }\end{array}$ & $\begin{array}{c}\text { multiple parties in power, } \\
\text { left party has never had } \\
\text { successive terms in office; } \\
\text { trade unions not primary } \\
\text { working class actor }\end{array}$ \\
\hline
\end{tabular}

Fig. 1 Predictions of existing theory for distributive outcomes in São Paulo

"middle class progressive" and "lower class opportunity expansion". However, he saw these categories as "largely hypothetical" in the context of the US. Work in the urban literature that has looked beyond US cases for comparative leverage has critiqued the "regime" and "growth machine" frames, due to much greater variation in inter-city competition across countries (Davies, 2002; Stoker \& Mossberger, 1994). These critiques emphasize the possibility of social coordination for realizing programmatic redistribution in cities.

As a conceptual frame for analyzing the power of cities to act, "regime theory" is commensurate with a range of distributive outcomes. For example, the constraining effect of federal government regulations on municipal action in the US (Petersen, 1981) underscores that the vertical "cohesion" of national, sub-national, and local governments is a critical dimension for analyzing variation in urban governing regimes across national contexts.

Most comparative accounts of the social bases of development and state capacity, in which empirical variation of outcomes has been much more of a central concern, have analyzed national state institutions. The emphasis has been on variations of class coalitions aligned to programmatic political parties as enabling or disabling policies for economic development and/or redistribution (see Pzeworski, 1985; Esping-Andersen, 1990; Rueschemeyer et al., 1992). The role of left political parties in Latin America (Huber \& Stephens, 2012) and alliances between working class organizations in civil society and a left political party in the Indian state of Kerala (Heller, 1999) have been found to drive gains in both human development and economic growth. In democracies, under conditions of subaltern collective action in coalition with a programmatic political party, redistribution is possible, even given the structural constraints of global capitalism.

These "power-resources" approaches to theorizing the state and distributional outcomes are mirrored in the social movements literature. The "political mediation" model of social movement action has highlighted the need for a responsive political elite to react to movement demands to make them successful (Amenta et al., 2010). This literature has readily acknowledged a focus on cases in the United States (Amenta, 2014) and therefore assumes bureaucratic capacities that do not always exist. Even the more state-centric accounts of social movements in work on "political opportunities" takes for granted the question of state capacity beyond the capacity to repress movements (McAdam et al., 1996; Tarrow, 1994).

These approaches are consistent with the Brazilian case at the national level. The PT is a left political party aligned to a social movement unionist alliance of unions, social 
movements and intellectuals. However, these theories do not fit the case of São Paulo. A PT mayor has never won reelection in the city. Trade unions have not been the primary civil society actor associated with programmatic delivery of public goods in the city. And the ruling party in local government has rarely been aligned to the party in power at the national level.

Democratic institutional arrangements are a necessary condition for residents to organize freely, assert rights to stay in the city, and demand public goods in their neighborhoods. But how do these demands translate beyond regulatory change or legal enforcement into concrete delivery at a city-wide scale by local governments? The theoretical concepts of "embeddedness" and "cohesion" explain processes of change that bridge external social mobilization and the internal, organizational life of state institutions.

\section{Defining "embeddedness" and "cohesion"}

I define "embeddedness" as the connections of the local state to civil society that produce the ideas and influence for policy change that realize more equal distribution of public goods. And I define "cohesion" as the coordinating capacity of the local state to implement policy changes. The concepts adapt prior explanations of social bases of state action to unique dimensions of urban administration. The analytical usefulness of these explanations depends on our ability to wield them to explain institutional change over time, and not only why an institutional configuration produces a given outcome in a moment in time.

Classic explanations of the role of embeddedness in generating state capacities do not fully account for the range of influential social actors in the urban context (cf. Evans, 1995; Heller, 1999). On the one hand, the social sectors likely to induce changes in the distribution of public goods are not likely to be either business elites or traditional trade unions. Social movements for goods of collective consumption, such as housing or transportation, are much more likely candidates for "embedded" connections to local state institutions to drive change in the distribution of public goods. These movements are rarely as durable or as encompassing as the traditional social actors, such as unions, in the literature on social democracy in both northern Europe (see Esping-Andersen, 1990) and Latin America (see Huber \& Stephens, 2012). The mobilization of such movements articulates and builds popular pressure for distributive goals. The connections that these movements have to political parties and professional bureaucrats within the local state make it possible for these goals to enter the halls of formal power.

Social movements have a wide repertoire of strategies that could be considered oppositional on one end of the spectrum or clientelistic on the other. How do we know when the relationship of movements to the state is embedded? Network ties between movements and the state are a necessary, but not necessarily sufficient condition for "embeddedness" to exist. "Embeddedness" captures network ties that produce programmatic outcomes — that is, city-wide policies as opposed to discretionary or clientelistic ones.

Embeddedness of the local state in a sphere of movements is critical for generating the disciplining impetus for internal bureaucratic cohesion. Evans' approach focuses on the institutional sphere of the state and that of the market, along theoretical lines 
associated with Polanyi (1944), focusing on channels of communicating information across the social spheres of market and state. The approach advanced here considers embeddedness from a more meso-level understanding, commonly associated with Granovetter (1985). I focus not only on the abstract strength or weakness of network ties between actors in the civil society sphere and local state, but also the temporal structure of those ties.

In other words, sequencing matters for explaining variation in configurations of embeddedness and cohesion. The emphasis is not only on sharing information between different spheres of social action, but on the formation of durable bonds between actors both within and outside the state that can produce the disciplining power of coordination that defines "cohesion."

Institutional action at subnational scales is intrinsically about coordinating delegated authority from higher scales in order to deliver public goods. "Cohesion" therefore comprises two axes of coordinating capacities, which are relatively unique to urban government: "Vertical", which is the capacity of municipal institutions to coordinate delivery across institutions at state and federal levels; and "Horizontal", which is the capacity to coordinate across multiple line agencies at the municipal level. We can compare the function of "cohesion" in urban public goods distribution to the role of Weberian "autonomy" of state bureaucracies in driving economic development in East Asian developmental states (Amsden, 1989; Evans, 1995; Wade, 1990). This literature focuses on single national agencies that manage economic policy. Recent work has found pockets of bureaucratic effectiveness within a single economic agency in Ghana (McDonnell, 2017). In contrast, cities tend to be nested in intermediate sub-national and national levels of authority, and the delivery of public goods tends to cut across multiple agencies.

"Cohesion" is distinct from what is commonly referred to as "state capacity". The dominant, Weberian view of "state capacity" is that the rational, rule-following features of organization of personnel should produce effective bureaucratic action. The notion of discipline as a feature of bureaucratic coordination does not feature for Weber. This is, in large part, because his ideal type of bureaucracy describes a single agency aiming to act in a linear command structure. The Weberian view of state capacity therefore provides limited analytical purchase for describing bureaucratic action for delivering goods that require coordinating multiple agencies along with multi-scalar regulations and funding flows. This notion of disciplined coordination builds on a critique by Chibber (2002) that rule-following is not a sufficient condition for state bureaucracies to realize developmental aims: "In order for it to be effective as a developmental state, bureaucratic rationality must also be structured in an appropriate apportionment of power among state policy agencies" (p. 952, emphasis in original).

Social bases of state effectiveness cannot be theorized without an explanation of change over time. This historical analytical strategy builds on an established tradition in the comparative study of the social basis of urban politics, including the role of urban social movements (Castells 1984), the political economy of urban regimes in the US (Fainstein et al., 1983), housing policies in the US and Europe (Fainstein, 2010), and urban management in India and China (Ren, 2020).

I find that configurations of embeddedness and cohesion exhibit aspects of both path-dependence and institutional indeterminacy — structural weaknesses that allow for agentic change. For movements to build lasting reform in state institutions, they 
need to navigate the institutional architecture established through past struggles. This means reckoning with the lasting influence of private real estate actors who act as central power brokers in urban politics.

I focus on the temporal dynamics of within-case variation through the case study of São Paulo. The precise sequence of change matters for assessing the causal pathways for the construction of institutional capacity to distribute public goods. We care not only about what configuration exists, but also about the order in which these configurations change. Specifying the configuration and sequencing of these two factors embeddedness and cohesion - makes it possible to categorize and compare how local political power is coordinated in cities (see Fig. 2). I illustrate how these categories travel to other comparative cases in the concluding discussion.

\section{Methods}

The city of São Paulo is chosen as a "least likely" case (Gerring, 2005) for the observed outcome of periods of sustained commitment and delivery in the redistribution of public goods. I rely on recent analysis of national and municipal census data of material change in the distribution of housing and sanitation in the city between 1991 and 2010 to specify the material improvements in housing and sanitation that make São Paulo a "least likely case" for analysis.

In order to identify the institutional mechanisms that explain this outcome, I draw on fieldwork conducted in São Paulo between 2016 and 2017. This includes: a) 110 semistructured interviews ${ }^{6}$ with current and former high and mid-ranking officials in government departments, mayors, city councilors, housing activists in professional non-governmental organizations and grassroots movements, private property developers, and executives in the São Paulo state sanitation company known by its acronym SABESP; and b) archival research of legislation, newspapers, professional trade publications, and internal government and NGO documents.

My aim in the interviews and archival work was to identify relationships between key actors, institutional spaces, and events that explain how institutional arrangements for distributing public goods have changed over time in São Paulo. I used snowball sampling until I reached a point of saturation for each type of actor. I used archival documentation to corroborate or call into question accounts from interviews, as well as to assist in triangulating from contradictory accounts from different informants. I collected legislative documents and urban plans in order to understand formalization of political decisions.

I draw on these data to construct a historical account of change in local state institutions in São Paulo. This account relies on specifying sequences of change, which roughly correspond to different mayoral administrations. This approach leverages variation between the case of São Paulo and general expectations of existing theory, and within-case variation across time periods. Such a sequential method, or "process tracing", is useful "for establishing the features of the events that compose individual sequences (e.g., their duration, order, and pace) as well as the causal mechanisms that link them together" (Faletti \& Mahoney, 2015, p. 212).

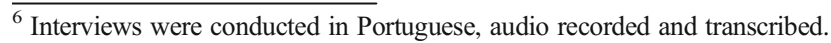




\begin{tabular}{|c|c|c|c|}
\hline \multicolumn{2}{|c|}{} & \multicolumn{2}{|c|}{ Embeddedness } \\
\cline { 3 - 5 } \multicolumn{2}{|c|}{} & \multirow{2}{*}{ Low } & \multicolumn{1}{c|}{ High } \\
\hline \multirow{3}{*}{ Cohesion } & Low & narrow elite capture & $\begin{array}{l}\text { mobilizational } \\
\text { redistribution-oriented policies } \\
\text { without financial and } \\
\text { administrative capacity }\end{array}$ \\
\cline { 2 - 4 } & High & $\begin{array}{l}\text { managerial } \\
\text { programmatic top-down } \\
\text { administration, often growth- } \\
\text { oriented }\end{array}$ & $\begin{array}{l}\text { integrationist } \\
\text { effective administration of } \\
\text { redistribution-oriented policies }\end{array}$ \\
\hline
\end{tabular}

Fig. 2 Configurations of embeddedness and cohesion

\section{São Paulo's sequences of embeddedness and cohesion}

I find that there are four key periods, or "regimes," in this sequence of configurations between state and society. I code each period as either "high" or "low" along the axes of "embeddedness" and "cohesion" (see Fig. 2). Housing and sanitation require coordination with other policy domains, including planning and land use. As particularly difficult policy areas, they are useful for specifying institutional conditions for effective delivery.

Sequential process tracing across four periods makes it possible to explain both why and when the city's governing regime of public goods has enabled this redistribution. The findings are summarized in Fig. 3 below. Each period maps onto a quadrant in Fig. 2. The first mayoral administration after the new Federal Constitution of 1988 was led by the PT from 1989 to 1992. This is an example of what I call an "mobilizational regime." Local state institutions were newly embedded in a social movement sphere that supported the introduction of redistributive policies that motivated ongoing mobilization of housing movements. This "mobilizational regime" made it possible to introduce new policy ideas for an expanded redistributive role for the local state that could deliver to the movements demanding housing improvements. However, achieving administrative cohesion was an unlikely and, ultimately, unrealized task. The second and third mayoral administrations were led by allied right-wing parties from 1993 to 2000 . This is an example of what I call a "rentier regime." It represents a period in which narrow groups of elites could realize profits, but the city did not realize a more programmatic growth agenda.

What followed was an "integrationist regime." For the first time, we see significant continuity across parties, due to an integrated configuration of "embeddedness" and "cohesion". This encompassed a PT administration and subsequent center-right administrations from 2001 to 2012. The growth of a federal legal and fiscal framework for empowering the administrative capacities of municipalities reinforced the trans-partisan

\footnotetext{
${ }^{7}$ See the distinction that Shambayati (1994) made between tax-based and rentier regimes. Large urban infrastructure projects like roads can be thought of us as rent-generating projects, like Shambayati's example of oil in Iran.
} 


\begin{tabular}{|c|c|c|c|}
\hline & Embedded & Cohesive & Outcome \\
\hline $\begin{array}{l}\text { Mobilizational } \\
\text { Erundina (left) } \\
1989-1992\end{array}$ & + & 一 & $\begin{array}{l}\text { Increased investments in } \\
\text { redistributive policies } \\
\text { No persisting institutional capacity } \\
\text { for implementation }\end{array}$ \\
\hline $\begin{array}{c}\text { Rentier } \\
\text { Maluf/Pitta (right) } \\
1993-2000\end{array}$ & - & 一 & $\begin{array}{l}\text { Particularistic basis for } \\
\text { distribution, concentrated amongst } \\
\text { traditional elite }\end{array}$ \\
\hline $\begin{array}{c}\text { Integrationist } \\
\text { Suplicy (left) } \\
\text { Serra/Kassab (right) } \\
2001-2012\end{array}$ & + & + & $\begin{array}{l}\text { Increased investments in } \\
\text { redistributive policies } \\
\text { Strong capacity for implementing } \\
\text { this agenda }\end{array}$ \\
\hline $\begin{array}{c}\text { Managerial } \\
\text { Haddad (left) } \\
2013-2016\end{array}$ & - & + & $\begin{array}{l}\text { Strong institutional capacity for } \\
\text { implementing programmatic } \\
\text { policy, but declining influence for } \\
\text { redistributive policy agenda }\end{array}$ \\
\hline
\end{tabular}

Fig. 3 Sequence of São Paulo's regimes of urban public goods distribution

dynamic at the municipal scale. The final mayoral administration, under the PT from 2013 to 2016, was a "managerial regime". Housing movements were increasingly subordinated in local politics and ended up targeting federal as opposed to municipal policies. The local state lost its embedded character. Weak embeddedness under a leftwing party eroded prior institutional cohesion to implement its policy agenda.

We can discern three patterns in this sequence. First, a causal role for sequencing in determining the ebbs and flows - what Mahoney (2000) calls "reactive sequences" — of embeddedness. Second, a secular trend towards increasing cohesion. And third, relative indeterminacy in municipal electoral politics, with power regularly changing hands between political parties of varied ideological commitments.

\section{The mobilizational regime: Luiza Erundina (1989-1992)}

The social movement sphere that brought Luiza Erundina to power provided a strong basis for embedding the local state in a new set of distributive demands. But her mayoral administration struggled to build the cohesion necessary to institutionalize them. The first generation of movements in the city emerged in the 1970s and 1980s, as rapid urban industrialization and growth put significant pressure on housing availability. In particular, the extreme eastern and southern parts of São Paulo were home to new land occupations and the growth of informal settlements (Holston, 2008). By the early 1980s, many of the neighborhood associations that had led these occupations were uniting under the common banner of the Federation of Housing Movements, or UMM (Earle, 2012). The UMM was influenced by Catholic liberation theology priests in the peripheries. These were the areas of the city with the most rapid growth of in-migration and the neighborhoods most deprived of 
access to public goods. Veteran leaders of the UMM reported that they first got involved in organizing around the issue of housing through their Catholic church.

The multi-vocal eco-system of housing movements was instrumental in shaping the electoral base of all three PT mayoral administrations in São Paulo's local state, in 19891992, 2001-2004, and 2013-2016. Governing programs for all PT electoral campaigns in the city were debated with housing movements, and professionals affiliated with movements occupied prominent positions in all three elected administrations. UMM leaders and city councilors frequently mentioned this relationship. This was decisive in embedding the municipal state in civil society under the Erundina administration. Movements in this period were involved in many of the self-build (mutirão) housing projects that were supported by Erundina's government.

Her administration was therefore well-placed to construct embedded ties between the state and the sphere of housing movements. Erundina was a social worker in the city's eastern zone and had longstanding connections with many of the neighborhood movement of the city's periphery. One UMM leader argued that this background enabled approval for her community's mutirão project in southern periphery of the city: "[Erundina] practically knew all of the favelas in the city. I would mention the name of a neighborhood and she would say that she already knew it." 8

Erundina, who speaks with a thick rural accent, was known across the eastern zone as a "woman of the people." In 1988, she won her mayoral seat in a first-past-the-post election, taking $29.8 \%$ of the vote. Despite her narrow electoral mandate, she promised to run the city with an "inversion of priorities" in order to establish the "PT way of governing" (Singer, 1995).

Even with a constrained municipal budget in a time of high inflation, the Erundina administration focused on redistributive programs for public goods. The administration made use of national social welfare funds to seed housing and slum upgrading programs in peripheral areas of the city. This included funding for the self-build housing programs demanded by housing movements. Both Erundina and her right-wing successor, Paulo Maluf, spent $3 \%$ of the total municipal budget on housing. In the same period, the Erundina administration funded the construction of 10,000 more houses than Maluf (Folha de São Paulo, 1996).

The Catholic church and housing movements were the primary backers of Erundina's candidacy within the PT (Couto, 1995). In part, this was because of the intellectual and political leadership of both liberation theology priests and a generation of architects and urban planners that began working with communities in the favelas of São Paulo's periphery. These professionals formed groups offering technical assistance (asistências técnicas) to neighborhood associations.

The banner of "urban reform" became these professionals' main political input to the PT agenda. Progressive architects and planners began working in asistencias técnicas before the first PT administration. Mario Covas, an appointed mayor of the MDB, then the only legal opposition party, began funding slum-upgrading projects in the peripheries, during the early democratic opening in Brazil from 1982 to 1985. These few projects produced key modalities for slum upgrading and self-build housing that scaled up under Erundina (Abiko \& Oliveira Coelho, 2004).

\footnotetext{
${ }^{8}$ Interview with the author, 27 June 2016.
} 
A key researcher-practitioner of this era was Nabil Bonduki, who would become the second highest official in Erundina's housing department. His experience with selfbuild, mutirão projects was instrumental in making this part of housing policy. Funding for mutirões was a priority of housing movements after Erundina's election. Bonduki took this demand into the bureaucracy, creating of a municipal fund for slum upgrading known by its Portuguese initials of FUNAPS. This fund was designated for projects managed by housing associations linked to movements.

According to both housing movement leaders and officials in the Department of Housing, Erminia Maricato, the department's top official, was initially opposed to selfbuild projects due to concerns about quality control of the self-build process. When I spoke with her, she said that she learned to take pride in these self-build projects, which she viewed as of much higher quality and much cheaper than the few large-scale projects undertaken by the subsequent mayoral administration of Paulo Maluf. It took bureaucrats like Bonduki, who had extensive links to housing movements, to bring movement demands into the formal policy-making process. Maricato told me that Erundina insisted that municipal staff open their doors to these movements.

"In that period, social movements would occupy our offices, one week on, one week off. They always wanted to speak with us. My life wasn't easy because they were placing constant demands on our office." 9

Many young planners and architects who had been working with housing movements got their first taste of government bureaucracy in the Erundina years. Geraldo Juncal, who had just qualified as an architect, described the "capillary" work of city government architects who were based in peripheral neighborhoods of the city:

"The difference, I think, was the capillary nature of policy. You had technical officials in different parts of the city who worked directly with the people, the people were their primary reference point, and they were always near a housing project. This was the embryo of what we called 'local government.",10

Juncal's contemporaries in this group, many of whom ended up in senior posts in housing and planning under subsequent mayoral administrations, recounted similar experiences under Erundina. The social housing division of the housing department under Bonduki doubled its staff complement, from 350 to 700 , comprising $58 \%$ of the total staff complement in the housing department (Cities Alliance, 2004). The purpose was to bring a significant corps of activist planning professionals from the asistencias técnicas into the "street-level" of the housing bureaucracy.

The Erundina administration's focus was to re-orient services towards the urban periphery that had been woefully underserved by prior administrative logics that saw the peripheries exclusively as a cheap labor reserve for centrally-located business activity. Though her government faced a constrained municipal budget and a minority in the city council, it produced a vision of redistribution in the city that was embedded in the civil sphere of housing movements.

\footnotetext{
${ }^{9}$ Interview with the author, 21 June 2016

${ }^{10}$ Interview with author, 24 May 2017
} 
But this was by no means a cohesive regime. Political attacks in the courts and in the press made implementation difficult. Erundina only ever had minority support in the city's legislature, and had continuous struggle to get her budgets approved. Despite creating new municipal funding arrangements for movement-led slum upgrading, few funds were available from state and national government to support these efforts. A court-imposed reduction in the increasingly progressive property tax made it difficult to continue to cross-subsidize spending on public goods across the geography of the city, from the wealthy core to the poor periphery. The case in the Court of Municipal Accounts was brought by opposition representatives in the municipal legislature. One former president of the São Paulo state chamber of real estate developers, SECOVI, was blunt in his description of her administration, describing her as "a northeasterner elected here in our city who was a total disaster."11 The municipal administration's combative relationship with right-wing controlled state and federal governments sealed this lack of cohesion. The PT's chosen successor to Erundina was defeated by $17 \%$ in the second round of the 1992 mayoral election (Patarra, 1996).

I describe the first mayoral administration of the PT in São Paulo as a "mobilizational regime" because its embeddedness in a civil sphere of housing movements established new guiding priorities for the distribution of public goods. This would continue to serve as a benchmark for subsequent mayoral administrations. However, its lack of institutional cohesion made it difficult to achieve programmatic outcomes in practice and particularly vulnerable to reaction.

\section{The rentier regime: Paulo Maluf and Celso Pitta (1993-2000)}

If the Erundina administration lanced the boil of traditional urban political economy in São Paulo, the years of Paulo Maluf (1993-1996, of the Popular Party) and Celso Pitta (1997-2000, of the Brazilian Progressive Party), were the virulent effect. Under Erundina, a local state embedded in a sphere of housing movements could not deliver effectively. This enabled a backlash that brought to power representatives of a particularistic elite. Under a rentier regime, some business elites can realize profits, but the city does not realize a more programmatic growth agenda. In São Paulo, during this period, low embeddedness combined with continued low institutional cohesion.

Maluf was known for large public works projects that mostly benefited wellestablished neighborhoods in the city, and for using these projects to fund narrow patronage networks. This was the basis for Maluf's enduring nickname of "rouba mas faz" ("he steals, but he gets things done"). As an electoral figure, Maluf was a representative of the traditional establishment, his formal political career having been forged during the military dictatorship (Puls, 2000).

Pitta was much weaker. The first Afro-Brazilian mayor of the city, he was not as personally connected to traditional brokers of power. His rise was prefigured by Maluf's strong endorsement as he left office. Pitta never established an independent political base (Estadão, 2009).

\footnotetext{
${ }^{11}$ Interview with the author, 11 July 2016. The reference to a "northeasterner" was clearly intended as pejorative descriptor. Brazil's northeast is the country's poorest region and, historically, the dominant source of migrants to cities in the country's wealthier south, such as São Paulo.
} 
To the extent that he was concerned with the distribution of public goods, Maluf focused on using the municipal housing company, $\mathrm{COHAB}$, to build high-rise buildings that often hid much larger favelas. These projects were called "Cingapuras", named after state-led housing projects in Singapore. Under both Maluf and Pitta, there was no public housing outside of the "Cingapura" developments. These did little to actually provide security of tenure and housing to the still largely informal populations of the city's periphery.

While this period witnessed the emergence of new business nodes in the western part of the city, they were not pursued on a programmatic basis. Beginning in the mid1990s, new development zones in the western part of the city were dedicated to the particular interests of a few local developers. Favelas were evicted to make way for high-rise buildings that became home to the Latin American headquarters of multinational firms (Fix, 2007). Leaders from UMM argued that fights against these evictions as well as against the paralysis of Erundina-era housing programs made the Maluf-Pitta era one of the most mobilized periods in the movement's history. ${ }^{12}$ Claudio Bernardes, a recent president of SECOVI, and other leading developers with whom I spoke, viewed the broader period of right-wing rule by Maluf and Pitta as a period of weak governance. ${ }^{13}$

Housing movement protests again favela removals and the poor quality of housing units increasingly discredited the Cingapuras, described by the city's leading daily newspaper as "one of the principal electoral banners" of Maluf and Pitta (Folha de São Paulo, 1999a). Pitta ended his term claiming to want to return to the "Erundina line" through a focus on self-build low-income housing programs (Folha de São Paulo, 1999b). This led Maluf to brand Pitta a "traitor", going so far as to suggest that Pitta be impeached (Folha de São Paulo, 1999c).

The rentier regime of Maluf and Pitta courted confrontation with housing movements while delivering narrowly-distributed profits through a series of poorly coordinated private real estate and public infrastructure projects. The reaction in the movement sphere held the promise of renewed embeddedness in a subsequent configuration of the local governing regime.

\section{The integrationist regime: Marta Suplicy (2001-2004), José Serra (2005-6) and Gilberto Kassab (2007-2012)}

The "integrationist regime" that spans the PT's Marta Suplicy and the center-right governments of José Serra and Gilberto Kassab put these distributional priorities on a more durable and programmatic path. This can be explained by the configuration of high degrees of institutional cohesion to complement the local state's renewed embeddedness in civil society.

The Suplicy administration was, like Erundina's, characterized by a mobilized social base of housing movements and allied unions. In contrast to Erundina, Suplicy's political strategy was openly reconciled to the traditional mode of favor-trading with other political parties ahead of the election in order to secure a workable majority for passing legislation in the city council (Folha de São Paulo, 2000). This presaged the

\footnotetext{
12 Interview with the author, 27 June 2016 and 6 July 2016.

${ }^{13}$ Interview with the author, 11 July 2016
} 
institutionalization of the Suplicy administration's priorities beyond the working class base of the PT and, ultimately, across party lines.

A second generation of housing movements had emerged in the late 1990s as an outgrowth of the UMM in São Paulo. Disinvestment of the city center in the 1990s under Maluf and Pitta had led to a loss of population in these central areas. Younger activists occupied abandoned buildings in the city center and refurbished them. Leaders of this new generation reported to me that their aggressive style grated on older movement activists who had become accustomed to the boardroom jujitsu of negotiations with local authorities for accessing land and housing. ${ }^{14}$ The new groups were eventually ejected and formed the umbrella Front for the Housing Struggle (FLM). FLM-affiliated groups built their own links to PT politicians in the Suplicy administration, and the city's housing department began a new program designed to attend to the concerns raised by FLM-affiliated groups in the city center. Both UMM and FLM leaders were quick to emphasize to me that despite previous differences, they now work together closely. ${ }^{15}$

In 2002, the PT won its first national election and Luiz Inácio "Lula" da Silva assumed the presidency. A new Ministry of Cities was initially staffed by figures from São Paulo housing activist circles, including officials from the Erundina administration. The creation of this ministry made it possible to reinforce the Suplicy administration's priorities through federal injection of funds for housing, sanitation and transportation, the three focus areas of the ministry.

Further, a new federal law, the City Statute of 2001, created a planning framework that helped produce cohesion across governing scales, and construct a self-reinforcing interaction of embeddedness and cohesion. The passage of master plans in São Paulo have been key moments for two reasons: First, these are moments that have made it possible to reconnect housing movements to their political allies within the PT. Second, these are moments when housing movements and the private real estate sector, while at odds, generate a common language of policy debate. These master plans have used concepts in the federal constitution of 1988 and the City Statute of 2001, especially concerning the "social function" of property, to designate areas as Zones of Social Interest (ZEIS) and to regularize areas without individual title. ${ }^{16}$ This made it possible to use the zoning code to take well-located land off the market for social housing provision and to enable to install water and sewer connections on land without formal title. (Fernandes, 2007).

São Paulo's master plan of 2002 was the first of any major Brazilian city to come after the passage of the federal City Statute, which empowered municipalities to pass master plans. The City Statute was the product of two decades of activism by the Urban Reform Movement, which drew mainly from urban professionals and activists from sectors such as architecture, engineering, and planning (Junior Nelson, 2001). A senior leader of the UMM said that the emphasis on master planning under Suplicy, "introduced the concept of ZEIS and housing movements made this a major part of our agenda." He argued that the willingness of the Suplicy administration to use new national legal tools to become one of the first major cities in the country to pursue a master plan, created new opportunities for a programmatic redistributive agenda for housing movements. ${ }^{17}$

\footnotetext{
${ }^{14}$ Interview with the author, 5 June 2017.

${ }^{15}$ Interview with the author, 12 June 2017. For more on the umbrella of the Popular Movements Front (CMP) see Earle, 2012.

${ }^{16}$ Municipal decree number 44.667, 26 April 2004.

${ }^{17}$ Interview with the author, 6 July 2016.
} 
The municipal housing council and public meetings about the master plan convened both housing movements and real estate sector representatives. Concepts like ZEIS were a response to housing movement occupations. But they have made it possible for otherwise opposed interests to mediate conflicts in a formal arena that is empowered to translate such mediation into policy change (Tatagiba et al., 2012). Whereas informants in housing movements emphasized their interest in upholding the "social function of property" in participatory councils, private sector informants consistently emphasized the sanctity of rights to private property. SECOVI has had the same point person representing the chamber in public councils and master planning processes since the Erundina administration, who described the deliberative dynamic:

When you enter into the game of the master plan, you have to enter — and I'm speaking as a representative of a stakeholder, or as a leader of a housing movement - we can't enter this game thinking that we're going to get everything that we want. The master plan, for it to be good for our city, it should mediate and perceive what is relevant from society's point of view, what is the public interest. ${ }^{18}$

This perspective underscores how institutional processes, especially under the Suplicy administration began to create a mechanism for ensuring that the real estate sector shaped its strategies to account for the distributional demands of housing movements. For example, leaders of the FLM described the master planning deliberations in 2002 as a moment where the movement learned to negotiate demands for the expropriation of vacant private buildings. ${ }^{19}$

São Paulo's electorate has historically had a center-right tilt and has never re-elected a PT mayor. In her 2000 victory, Suplicy could occupy the center ground in the city's run-off election against a candidate of the extreme right, Paulo Maluf. In the 2004 runoff, she faced off against a traditional centrist candidate of the center-right PSDB, José Serra. Redistributionist claims in the realm of public goods governance in São Paulo moved from a single party affiliation to a capable trans-partisan administration. Significant injections of support for redistributionist public goods policies were now available at the federal level, which was controlled by the PT.

A new federal legal framework set the stage for increased administrative cohesion. The National Sanitation Law of 2007 enabled the São Paulo municipality to take a more hands on approach to extending sanitation networks to favelas. SABESP has a strong internal culture, long considered by municipal officials to be impervious to their needs. Since undergoing a partial privatization in the 1990s, the company had faced accusations of prioritizing its balance sheet over social goals. But the National Sanitation Law gave the municipality new regulatory authority, as well as the right to capture a portion of revenues from SABESP for the purpose of slum upgrading. Both SABESP and municipal officials reported that this had the effect of both making the city an administrator of SABESP and making SABESP more focused on municipal priorities, especially in informal settlements. A joint municipal-SABESP administrative committee was established to govern these operations and to liaise with the new São Paulo

\footnotetext{
${ }_{18}$ Interview with author, 29 September 2017

${ }^{19}$ Interview with author, 5 June 2017
} 
utility regulator established under the National Sanitation Law. Such "vertical" cohesion routinized the inclusion of favela neighborhoods in the governance of basic infrastructure in the city.

Though there was changeover in mid and high-level staff in the housing department, its redistributive emphasis was entrenched. There was significant continuity of staff across PT and center-right administrations, according to recent network analysis of bureaucratic appointments (Marques, 2017). I spoke with three senior bureaucrats from this period who had continuous tenures dating back to the Erundina administration. Ricardo Pereira, housing secretary under Kassab, was previously in the leadership of SECOVI. He argued that he was quickly acculturated to the policy orientation of career bureaucrats when he entered municipal government: "Look, in the private sector you are a capitalist. But when you enter the public sector you become a communist."20

Senior officials in the housing department under Serra and Kassab compared their work in slum upgrading favorably to that of the PT, citing work in favelas in the far south of the city. ${ }^{21}$ These officials credit both the combination of social movement pressure and increased alignment between sanitation investments by SABESP and municipal plans for making these projects possible. França, who directed many of these slum upgrading efforts in the southern parts of the city, described a critical role for housing movements: "In São Paulo, we have serious movements. They have histories and representativity. And they should exist, no? They are always there fighting. And public authorities are sometimes struggling to keep up with them ${ }^{22}$ ".

França spearheaded some of the most difficult slum upgrading projects in the city's history, focusing on of the largest contiguous zones of informal settlements in the south of the city, near the Guarapiranga Dam. These projects were so problematic because of the technical challenges in delivering new water and sewer infrastructure in dense, lowlying neighborhoods right next to a body of water. The informal settlements in the Guarapiranga Reserve were deprioritized over water quality in the dam itself during periods when SABESP had exclusive control over planning for extension of infrastructure due to their technical difficulty. In fact, the focus on slum upgrading in the Guarapiranga Reserve had been mooted since the Erundina administration, and had a renewed emphasis under Suplicy. With new funds and regulatory power from the federal government, França was able to act. Her housing department emphasized incorporating informal settlements into the formal infrastructures of the city. It could now push SABESP to deliver services to what were some of the most deprived informal settlements anywhere in the city.

Federal government created necessary, but not sufficient conditions for the interscalar dimension of cohesion through the law (eg. the City Statute of 2001 and the National Sanitation Law of 2007) and the budget (new funds for slum upgrading and a low-income housing subsidy). In this period, we see increased cohesion in both the "horizontal" and "vertical" dimensions. Horizontal cohesion is illustrated by the continuity of bureaucrats across mayoral administrations and integrated master plans that focused line agencies on common goals and accounted for the full geography of the city. Vertical cohesion is illustrated by increased accountability of the federal

\footnotetext{
${ }^{20}$ Interview with the author, 4 May 2017

${ }^{21}$ Interviews with author, 4 July 2016 and 17 October 2017

${ }^{22}$ Interview with the author, 4 July 2016.
} 
government and the state-level SABESP to support distributional goals of municipal authorities.

Increased administrative cohesion explains this period's consolidation of the redistributive regime. But this introduced new forms of instability to the durability of local state embeddedness. While housing movements continued to make demands on the local state, their attention moved to new national programs, like urban infrastructure grants and a federal housing subsidy.

\section{The managerial regime: Fernando Haddad (2013-2016)}

The administration of Fernando Haddad, an academic who had served as a minister in Lula's governments, was a period when we begin to see the sources of fragility in the sequential dynamics in "embedded cohesion". The length and durability of the prior "integrationist" period across a center-left and then center-right mayoral administrations bred a complacency about "embeddedness." When the PT took over once again under Haddad, it inaugurated a more top-down, "managerial" style for a center-left administration. Upon leaving office at the end of 2016, Haddad did not point to a redistributive outcome as the major achievement of his tenure, instead highlighting improved finances, a new public works plan, and a new master plan (Scruggs, 2016).

The campaign was marked by the São Paulo PT's increasing distance from housing movements. Haddad chose to include as a coalition partner Maluf's right-wing PP, with an agreement to grant the PP the housing portfolio. This deviated from expectations set during the only other municipal coalition government led by the PT in São Paulo, under Suplicy. Her housing secretary had been Paulo Teixeira, a PT student activist and human rights lawyer with links to housing movements in the eastern periphery of the city, where he grew up. Haddad's approach to coalition-building led Erundina to end her support for the ticket. One senior leader of UMM told me that housing movements viewed the inclusion of the PP as "absolutely horrible.",23

The Haddad administration's lack of embeddedness can be explained in two ways, which need not be seen as exclusive. First, housing movements - the PT's partner for realizing an embedded regime - were increasingly focused on the growing subsidies from the federal housing program called My House My Life, and did not mobilize the mass support for city-wide policies that they had commanded in earlier years. A new, third generation of movements united under the banner of the Homeless Worker's Movement (MTST) in the mid-2000s. MTST mostly shunned engagements with formal participatory institutional structures, such as the municipal housing council. MTST occupations in the São Paulo metropolitan region began in the mid-2000s, though rarely within the boundaries of the municipality of São Paulo. Occupations are large, often topping 1000 families. $^{24}$ The movement's notoriety among elite paulistanos is such that they were the only movement described as a true antagonist by property developers whom I interviewed. Leaders of all three generations of housing

\footnotetext{
${ }^{23}$ Interview with the author, 8 May 2017.

${ }^{24}$ Interview with the author, 12 June 2017. I made multiple visits to two different MTST occupations and spoke with local leaders of these occupations.
} 
movements increasingly considered the federal subsidy the only game in town for social housing due to its scale compared to municipal programs.

Second, the Haddad administration was characterized by institutional cohesion across scales despite some inter-personal political conflict with the federal government. In a reflection on his time in office, published in a popular monthly magazine in May 2017, Haddad criticized Lula's successor, Dilma Rousseff, for not prioritizing federal investment in São Paulo (Haddad, 2017). Interviewed shortly after this article's publication, Haddad told me that his regular contact with the national PT was with Lula and that he almost never spoke with Rousseff. ${ }^{25}$ Without a strong connection to local social mobilization, Haddad was reduced to weak personal appeals to continue to build inter-scalar, "vertical" cohesion.

Despite these weaknesses, the Haddad administration was still able to draw on the gains of the prior "integrationist" configuration of "embeddedness" and "cohesion" regime. After the 2002 master plan, the subsequent center-right administrations of Serra and Kassab (2006-2012) pursued a planning vision that was often aligned to the interests of developers especially through the new zoning tool of "urban operations" (Alvim et al., 2011). Even so, the Serra and Kassab administrations faced binding constraints for land use enumerated in the 2002 master plan.

Haddad would extend these restraints for market-driven development in a new master plan passed in 2014. The key instrument here was the demarcation of additional ZEIS in order to continue to relativize private property rights, especially in centrallylocated areas, which theoretically expanded the scope of well-located low-income housing. In the 2014 master plan, Haddad tried to present himself as an urbanist modernizer, who could demonstrate a new twenty-first century "PT way of governing," just as Erundina had done in 1989. He told me that he aimed to establish a new "socioenvironmental" political coalition, exemplified by a program to build a network of bike lanes throughout the city.

In June 2013, six months after Haddad took office, protests erupted against a proposed hike in public transport fares. The protests morphed into more generalized protests against corruption and took on an increasingly middle-class tinge that criticized the entire political class (Alonso \& Mische, 2016; Purdy, 2017). This groundswell produced energy on the right to call for the impeachment of Lula's successor, Dilma Rousseff, which occurred shortly before Haddad's re-election bid in 2016. His campaign ended in an unprecedented failure. Beginning in 1992, every election required a second round run-off. In 2016, there was no need. João Doria of the PSDB, a business impresario and TV host of the Brazilian version of Donald Trump's "The Apprentice" was elected with $53 \%$ of the vote.

Haddad's "managerial regime" suggests that institutional cohesion can breed a topdown managerial governing style that makes it less likely for formal political leaders to tend to the "embedded" side of the equation. This weakness of the relationship between party, local state institutions, and the social movement sphere echoes Michels' theory of the "iron law of oligarchy" in political party organizations, as well as arguments in the social movement literature that highlights the tension between mobilization and institutionalization (Armstrong \& Bernstein, 2008; Baiocchi et al., 2012; Seippel, 2001).

\footnotetext{
${ }^{25}$ Interview with the author, 5 June 2017
} 


\section{Discussion}

My findings in São Paulo lead to the following generalizable expectations of what to expect in sequences of redistributive urban regimes in other democratic settings. A mobilized movement sphere that is connected to the local bureaucracy - high embeddedness - and a local bureaucracy with strong coordinating capacity - high cohesion - will result in improved distribution of public goods. While the cohesive dimension of an "integrationist" configuration is likely to be relatively durable, maintaining movement mobilization becomes increasingly difficult over time.

When the local state is embedded, but not cohesive, it does not have sufficient insulation to protect a redistributive political project from reaction by traditional elites. Such a "mobilizational" regime is necessarily focused on movement mobilization because it is not rooted in a cohesive institutional sphere. This lack of a sufficiently cohesive institutional web makes a mobilizational project vulnerable as soon as its political principals lose office. Neither the presence of left political parties nor a Weberian ideal type of autonomous bureaucrats is sufficient to prevent capture by traditional elites. These bureaucrats must be part of a cohesive institutional sphere.

Alternatively, when the regime is cohesive, even without embeddedness, it maintains path dependencies of prior regimes. In a "managerial" regime, the institutional sphere is characterized by high degrees of coordinating capacity across the two dimensions that define cohesion (vertical and horizontal). This makes it more difficult to pick apart the web of cohesive institutions to enact a political project in which rents are distributed narrowly to traditional elites. The political priorities of embedded regimes can be sustained, though not indefinitely, through a sufficiently cohesive institutional sphere even once the original political party is no longer in power.

Cohesion can also have the paradoxical effect of weakening embeddedness. It creates conditions under which the local state can implement a variety of programmatic projects. This can mean not only an orientation towards redistribution but for growth. The temptation is to rely on purely bureaucratic means to realize such a project. Embeddedness in civil society is the social mechanism through which redistributive politics gain an institutional foothold. The turn away from embeddedness weakens the cohesion of the state.

The São Paulo case makes clear that we can identify important variation in redistributive outcomes, even within a single case, and therefore need to theorize concepts to explain this variation. This is not to say that urban institutions in São Paulo have operated with total independence from larger forces. In fact, each of the factors that I have proposed to explain the redistributive regime of public goods in São Paulo incorporates structural forces that are often global and transnational. Dynamics of urban neoliberal restructuring under conditions of contemporary global integration of markets are undoubtedly part of the story. The power of housing movements in the city is rooted in the high degree of city residents who are excluded from formal housing, which has remained above $10 \%$ for the period under examination. Like embeddedness, a key dimension of cohesion is the role of inter-scalar relationships, thereby emphasizing the inter-dependence of city, state, and national scales of political and social action.

Cities are not merely dependent on what happens at larger scales, both from the perspective of economic and political structures. In short, local governments intervene. The sphere of the local state is a critical ground for understanding social conflict and change in cities. The question is to what extent local institutional interventions will 
achieve their aims and why those aims emerge in the first place. Mega-cities like São Paulo face significant challenges of coordination. Processes of institutional change must contend with histories of fragmented and clientelistic administration.

Calls continue to grow for concepts in the sociology of cities with comparative implications (Ren, 2018). But the sociology of cities too often avoids questions of institutional change at the scale of the city. Public goods distribution in cities is subject to observable variation. We need to elaborate the conceptual tool kit more concretely for explaining variation in cities, and not assume that capacities to realize governing aims are predetermined. Regimes of urban public goods distribution are constructed over time through sequential processes that can be traced empirically.

I argue that the configuration of the two factors of "embeddedness" and "cohesion" can help us categorize and compare how local political power is coordinated across cities. The four possible configurations were presented in Fig. 2. In my empirical analysis of São Paulo, I demonstrated how this approach is both configurational and sequential. Below, I illustrate how the conceptual tools can travel to different contexts. Different cities have different levels of inclusion in aspects of the built environment of the city. For example, sanitation access is universal in most cities in the richest countries. But conflicts over public goods - struggles over consumption - are common to all cities, and the conflicts over sanitation and housing that I examine in São Paulo have functional equivalents in cities where sanitation might be universal. Of largely universal significance is the role of local government in investing in social housing. Though, as I show below, the issue of water and sanitation infrastructure continues to drive political conflict even in cities in a rich country like the United States. While I do not address sequential dynamics here, the role of time in urban politics underscores that no city is immutably in one configuration (Fig. 4).

\begin{tabular}{|c|c|c|c|}
\hline & \multicolumn{2}{|c|}{ Embeddedness } \\
\hline & & Low & High \\
\hline \multirow[t]{2}{*}{ Cohesion } & Low & $\begin{array}{l}\text { rentier } \\
\text { narrow elite capture } \\
\text { Indian cities 2000s } \\
\text { Flint, MI 2011-2017 }\end{array}$ & 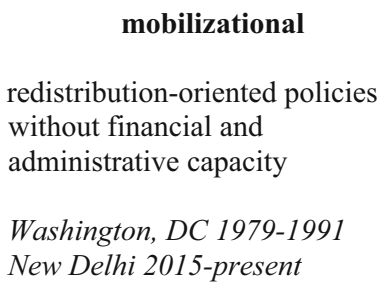 \\
\hline & High & $\begin{array}{l}\quad \text { managerial } \\
\text { programmatic top-down } \\
\text { administration, often growth- } \\
\text { oriented } \\
\text { modal US "growth machine" } \\
\text { Chinese mega-cities } 2000 \text { s }\end{array}$ & $\begin{array}{l}\qquad \text { integrationist } \\
\text { effective administration of } \\
\text { redistribution-oriented policies } \\
\text { Chicago, IL 1983-1987 } \\
\text { Amsterdam 1990s }\end{array}$ \\
\hline
\end{tabular}

Fig. 4 Comparative illustrations 
Rentier (low embeddedness-low cohesion) The informal, deregulated, and captured modes of urban planning in India have been found to be endemic (Roy, 2009). In the United States, an illustrative example is the municipality of Flint, which has been under the receivership of the state of Michigan since 2011 and has subsequently been providing poisoned water to city residents for the past three years. Civil society has been rendered almost irrelevant to formal politics, while private holders of municipal bonds were paid in full (Fasenfest, 2019).

Mobilizational (high embeddedness-low cohesion) Washington, DC, USA, under its first black mayor Marion Barry in the late 1970s and early 1980s, and New Delhi, India, under the Aam Aadmi Party since 2015 are two cases of reform-minded, social movement-backed administrations. Both are capital cities and are subject to national governments with significant power to undermine municipal policy changes. Opposing right-wing parties led each city's respective central government. As a result, each city had only limited financial independence to reorient the delivery of public goods on a programmatic basis, despite attempts to introduce reforms. In each case, the space of the city has seen limited change in the distribution and quality of public goods like housing (Diwakar, 2016; Thompson, 2006). In these cases, we see a strong demandside dynamic of social mobilization without interscalar — or "vertical" — cohesion.

Managerial (low embeddedness-high cohesion) As I have noted above, this configuration is most evident in the literature on "growth machines", in which a relatively capable local state coordinates with business elites to pursue the programmatic goal of economic growth. Another important - though non-democratic - case is large Chinese cities since economic reforms in the 1990s that decentralized borrowing authority to local governments. The hukou system of internal migration controls has produced extreme rationing of access to urban public goods along with a strong orientation to economic growth outcomes (Dreger et al., 2015). In both cases, the local state is cohesive enough to pursue a relatively programmatic project, but its managerial character does not guarantee human development objectives as the programmatic goal.

Integrationist (high embeddedness-high cohesion) Amsterdam, Netherlands, has managed to maintain high levels of investment in public goods, especially housing, which Fainstein (2010) attributes to both the legacy of squatters' movements in the city in the 1960s and 1970s, as well as commitments by the Dutch national government to invest in municipal services. Chicago, under its first black mayor Harold Washington from 1983 to 1987, is another example, though his untimely death shortly after he began his second term makes this harder to evaluate in terms of material outcomes. The coalition of working and middle-class black residents and liberal whites that backed his administration enabled it to direct funds and bureaucratic administration toward the development of previously marginalized neighborhoods in the city (Clavel \& Wiewel, 1991).

I conclude by suggesting two future directions that these comparative concepts make possible. Our political sociology of development needs to bring cities back in. Studies of comparative democratization and redistribution have focused on traditional actors of unions and parties. At the urban scale, we see the emergence of different types of influential organizations and actors, such as housing movements. These actors have been essential to driving outcomes that the role of parties, on their own, cannot 
adequately explain. To "bring cities back in" means not only to focus on issues of standard of living and collective consumption as driving forces of institutional change, but to treat the sphere of local state institutions as varied and socially contested.

And our sociology of cities needs to bring institutions of the state back in. Work on the structural foundations of urban change has identified undeniable shifts that characterize the realities of urban political economy. But the variable social world of urban politics continues to wield influence in changing the fates of the health, well-being, and social solidarities of people who live in cities. By making institutional change central to our empirical analysis of cities, we can realize a conceptual tool kit for systematically analyzing the variation of the distributional outcomes that will go a long way towards determining humanity's urban future.

Acknowledgments For their comments on drafts of this manuscript, I thank Anindita Adhikari, Nitsan Chorev, Daniel Aldana Cohen, Peter Evans, Patrick Heller, Ali Kadivar, Fenna Krienen, John Logan and Quinton Mayne. I benefited greatly from comments received at presentations of earlier versions of this work at the Center for Metropolitan Studies at the University of São Paulo, the Gauteng City-Region Observatory and the Public Affairs Research Institute at the University of Witwatersrand in Johannesburg, and meetings of the American Sociological Association, Society for the Advancement of Socio-Economics, and the American Political Science Association. I am indebted to those in São Paulo who took time to speak with me, share their experiences, and share documents for this research. All errors are mine.

Code availability Not applicable.

Funding I am grateful for peer-reviewed financial support from the American Council of Learned Societies, the National Science Foundation (Doctoral Dissertation Research Improvement Grant \#1802543), the Fulbright Foreign Scholarship Board, the Brazilian Studies Association, and intramural grants from Brown University's Graduate Program in Development at the Watson Institute for International and Public Affairs, the Institute at Brown for Environment and Society, and the Office of Graduate Education.

Data availability Upon request.

\section{Declarations}

Conflict of interest I declare no conflicts of interest.

\section{References}

Abiko, A. K., \& Oliveira Coelho, L. (2004). Procedimentos De Gestão De Mutirão Habitacional Para População De Baixa Renda. Ambiente Construido, 4(1), 7-20.

Alonso, A., \& Mische, A. (2016). Changing repertoires and partisan ambivalence in the new Brazilian protests. Bulletin of Latin American Research, 36(2), 144-159.

Alvim, A., Benatti, A. T., Abascal, E. H. S., \& de Moraes, L. G. S. (2011). Projeto Urbano E Operação Urbana Consorciada Em São Paulo: Limites, Desafios E Perspectivas. Cadernos Metrópole, 13(25), 213-233.

Amenta, E., Caren, N., Chiarello, E., \& Yang, S. (2010). The political consequences of social movements. Annual Review of Sociology, 36(1), 287-307.

Amenta, E. (2014). How to analyze the influence of social movements. Contemporary Sociology, 43(1), 1629.

Amsden, A. H. (1989). Asia's next Giant: South Korea and late industrialization. Oxford University Press. 
Armstrong, E. A., \& Bernstein, M. (2008). Culture, Power, and Institutions: a Multi-Institutional Politics Approach to Social Movements. Sociological Theory, 26(1), 74-99.

Arretche, M. T. S. (1999). Políticas sociais no Brasil: descentralização em um Estado federativo. Revista Brasileira de Ciências Sociais, 14(40), 111-141.

Baiocchi, G., Braathen, E., Teixeira, A. C. (2012). Transformation institutionalized? Making sense of participatory democracy in the Lula era. In Democratization in the Global South the Importance of Transformative Politics, edited by C Stokke and O Thornquist. Palgrave Macmillan.

Bonduki, N. (1994). Crise da habitação e luta pela moradia no pós-guerra. In Kowarick (Ed.), As Lutas Sociais e a Cidade - São Paulo: Passado e Presente. Editora Paz e Terra.

Becerril, H. (2017). Evictions and housing policy evolution in Rio de Janeiro: An ANT perspective. Journal of Urban Affairs, 39(7), 939-952.

Biderman, C., \& Lopes, M. (2015). The geographic dynamics of industry employment in Brazilian metropolitan areas: Lessons for São Paulo. Brazilian Journal of Political Economy, 35(3), 492-509.

Brenner, N., \& Theodore, N. (2002). Cities and the geographies of 'actually existing neoliberalism'. Antipode, 34, 349-379.

Caldeira, T. P. (2017). Peripheral urbanization: Autoconstruction, transversal logics, and politics in cities of the global south. Environment and Planning D: Society and Space, 35(1), 3-20.

Camargo, C. P. F., Cardoso, F. H., Mazzucchelli, F., Moisés, J. Á., Kowarick, L., de Almeida, M. H. T., Singer, P. I., \& Brant, V. C. (1976). São Paulo 1975: Crescimento e Pobreza. Edições Loyola.

Chibber, V. (2002). Bureaucratic rationality and the developmental state. American Journal of Sociology., 107(4), 951-989.

Alliance, C. (2004). Integrating the poor: Urban upgrading and land tenure regularization in the City of São Paulo. Cities Alliance.

Clarno, A. (2017). Neoliberal apartheid: Palestine/Israel and South Africa after 1994. University of Chicago Press.

Clavel, P., \& Wiewel, W. (1991). Introduction. In Clavel \& Wiewel (Eds.), Harold Washington and the Neighborhoods. Rutgers University Press.

Couto, C. G. (1995). O desafio de ser governo: O PT na prefeitura de São Paulo (1989-1992). Editora Paz e Terra.

Davies, J. S. (2002). Urban regime theory: A normative-empirical critique. Journal of Urban Affairs, 24, 1-17.

Davis, M. (2006). Planet of slums. Verso Books..

Diwakar, R. (2016). Local contest, National Impact: Understanding the success of India's Aam Aadmi party in 2015 Delhi assembly election. Representation: Journal of Representative Democracy, 52(1), 71-80.

Dreger, C., Wang, T., \& Zhang, Y. (2015). Understanding Chinese consumption: The impact of Hukou. Development and Change, 46(6), 1331-1344.

Earle, L. (2012). From insurgent to transgressive citizenship: Housing, social movement and the politics of rights in Sao Paulo. Journal of Latin American Studies., 44(1), 97-126.

Esping-Andersen, G. (1990). The three worlds of welfare capitalism. Princeton University Press.

Estadão. (2009). Conheça a vida e os escândalos de Celso Pitta. 21 November 2009. https://politica.estadao. com.br/noticias/geral,conheca-a-vida-e-os-escandalos-de-celso-pitta,469925. Accessed 2 January 2019.

Evans, P. (1995). Embedded autonomy: States and industrial transformation. Princeton University Press.

Fainstein, S. (2010). The Just City. Cornell University Press.

Fainstein, S., Fainstein, N., Hill, R. C., Judd, D. R., \& Smith, M. P. (1983). Restructuring the city: the political economy of urban redevelopment. Longman.

Faletti, T., \& Mahoney, J. (2015). The comparative sequential method. In Mahoney \& Thelen (Eds.), Advances in Comparative-Historical Analysis. Cambridge University Press.

Fasenfest, D. (2019). A neoliberal response to an urban crisis: Emergency Management in Flint. MI. Critical Sociology., 45(1), 33-47.

Fernandes, E. (2007). Implementing the urban reform agenda in Brazil. Environment and Urbanization, 19(1), $177-189$.

Fix, M. (2007). São Paulo cidade global. Boitempo Editoral.

Florida, R. (2017). The new urban crisis. Basic Books.

Folha de São Paulo. (1996). Mutirão versus Cingapura. 14 November, 1996. http://www1.folha.uol.com.br/ fsp/1996/11/14/caderno_especial/50.html. Accessed 17 May 2018.

Folha de São Paulo. (1999a). Cingapura foi maior destaque. 30 March 1999. https://www1.folha.uol.com.br/ fsp/cotidian/ff25059904.htm. Accessed 12 December 2018.

Folha de São Paulo. (1999b). Maluf chama Pitta de traidor e pede desculpas por tê-lo indicado. 24 April 1999. https://www1.folha.uol.com.br/fsp/cotidian/ff24049901.htm. Accessed 12 December 2018. 
Folha de São Paulo. (1999c). Pitta esquece Maluf e adota 'linha Erundina’. 25 May 1999. https://www1.folha. uol.com.br/fsp/cotidian/ff25059904.htm. Accessed 12 December 2018.

Folha de São Paulo. (2000). Aliança com novatos seria decisiva para PT.” 26 December 2000. https://www1. folha.uol.com.br/fsp/cotidian/ff2612200013.htm. Accessed 26 November 2018.

França, D. (2015). Desigualdades e segregação residencial por raça e clase na RMSP (2000-2010). In S. Marques (Ed.), A metropole de São Paulo no século XXI. Editora Unesp.

Gerring, J. (2005). Causation. Journal of Theoretical Politics, 17(2), 163-198.

Gibson, C. L. (2018). Programmatic configurations for the twenty-first-century developmental state in urban Brazil. Sociology of Development, 4(2), 169-190.

Granovetter, M. (1985). Economic action and social structure: The problem of embeddedness. American Journal of Sociology, 91(3), 481-510.

Haddad, F. (2017). Vivi na pele o que aprendi nos livros: um encontro com o patrimonialismo brasileiro. Revista Piauí, 129, 28-37.

Heller, P. (1999). The labor of development: Workers and the transformation of capitalism in Kerala, India. Cornell University Press.

Holston, J. (2008). Insurgent citizenship: Disjunctions of democracy and modernity in Brazil. Princeton University Press.

Huber, E., \& Stephens, J. D. (2012). Democracy and the left: Social policy and inequality in Latin America. University of Chicago Press.

Kowarick, L. (1980). A espoliação urbana. Editora Paz e Terra.

Krack Selzer, A., \& Heller, P. (2010). The spatial dynamics of middle-class formation in postapartheid South Africa: Enclavization and fragmentation in Johannesburg. Political Power and Social Theory, 21, 171208.

Logan, J., \& Molotch, H. (1987). Urban fortunes: The political economy of place. University of California Press.

Marques, E. C. L. (2017). A Rede Dos Gestores Locais Em São Paulo. Dados, 60(2), 437-472.

Marques, E. (Ed.). (2015). A metrópole de São Paulo no século XXI, Espaços, Heterogeneidades e Desigualdades. University of São Paulo Press.

Marques, E. (2014). Estrutura Social e Segregação em São Paulo: Transformações na Década de 2000. DADOS - Revista de Ciências Sociais, 57(3), 675-710.

Marques, E., \& Saraiva, C. (2017). Urban integration or reconfigured inequalities? Analyzing housing precarity in Sao Paulo, Brazil. Habitat International, 69, 18-26.

McAdam, D., McCarthy, J., \& Zald, M. (Eds.). (1996). Comparative perspectives on social movements. Cambridge University Press.

McDonnell, E. M. (2017). Patchwork leviathan: How pockets of bureaucratic governance flourish within institutionally diverse developing states. American Sociological Review, 82(3), 476-510.

de Oliveira, F. (1972). A economia brasileira: crítica à razão dualista. Estudos Cebrap, 2, 4-82.

Otávio, C. (2019). Seminário discutirá revisão do Plano Diretor do Rio de Janeiro. O Globo. December 12. https://oglobo.globo.com/rio/seminario-discutira-revisao-do-plano-diretor-do-rio-de-janeiro-23801975. Accessed 12 December 2018.

Patarra, I. (1996). O governo Luiza Erundina. Geração Editorial.

Petersen, P. (1981). City limits. University of Chicago Press.

Polanyi, K. (1944). The great transformation. Beacon Press.

Puls, M. (2000). O malufismo. Publifolha.

Purdy, S. (2017). Brazil's June days of 2013: Mass protest, class, and the left. Latin American Perspectives, $22(2), 1-22$.

Pzeworski, A. (1985). Capitalism and social democracy. Cambridge University Press.

Ren, X. (2020). Governing the urban in China and India. Princeton University Press.

Ren, X. (2018). From Chicago to China and India: Studying the City in the twenty-first century. Annual Review of Sociology, 44(1), 497-513.

Rocco, R., Royer, L., \& Gonçalves, F. M. (2019). Characterization of spatial planning in Brazil: The right to the City in theory and practice. Planning Practice \& Research, 34(4), 419-437.

Roy, A. (2009). Why India cannot plan its cities: Informality, insurgence and the idiom of urbanization. Planning Theory, 8(1), 76-87.

Rueschemeyer, D., Stephens, E. H., \& Stephens, J. D. (1992). Capitalist Development \& Democracy. University of Chicago Press.

Junior Nelson, S. (2001). Estatuto da Cidade: Instrumento da Reforma Urbana. In Estatuto da Cidade: Perspectivas para a reforma urbana. Instituto Polis. 
Scruggs, G. (2016). We managed to kick off a paradigm shift in São Paulo,' mayor says on leaving office. Citiscope. http://archive.citiscope.org/story/2016/we-managed-kick-paradigm-sh. Accessed 13 December 2018.

Seidman, G. (1994). Manufacturing Militance: Workers movements in Brazil and South Africa, 1970-1985. University of California Press.

Seippel, Ø. (2001). From mobilization to institutionalization? The case of Norwegian environmentalism. Acta Sociologica, 44(2), 123-137.

Shambayati, H. (1994). The rentier state, interest groups, and the paradox of autonomy: State and business in Turkey and Iran. Comparative Politics., 26(3), 307-331.

Singer, P. (1995). Um governo de esquerda para todos: Luiza Erundina na prefeitura de São Paulo (19891992). Editora Brasiliense.

Stoker, G., \& Mossberger, K. (1994). Urban regime theory in comparative perspective. Environment and Planning C: Government and Policy, 12(2), 195-212.

Stone, C. N. (1989). Regime Politics. University of Kansas Press.

Stone, C. N. (1993). Urban regimes and the capacity to govern: A political economy approach. Journal of Urban Affairs, 15(1), 1-28.

Tarrow, S. (1994). Power in movement: Social movements, collective action and politics. Cambridge University Press.

Tatagiba, L., Paterniani, S. Z., \& Trindade, T. A. (2012). Ocupar, reivindicar, participar: sobre o repertório de ação do movimento de moradia de São Paulo. Opin. Publica, 18(2), 399-426.

Thompson, J. P. (2006). Double trouble: Black mayors, black communities and the call for deep democracy. Oxford University Press.

Usmani, A. (2018). Democracy and the class struggle. American Journal of Sociology., 124(3), 664-704.

Wade, R. (1990). Governing the Market. Princeton University Press.

Publisher's note Springer Nature remains neutral with regard to jurisdictional claims in published maps and institutional affiliations.

Benjamin H. Bradlow is a Postdoctoral Fellow in the Weatherhead Scholars Program at Harvard University's Weatherhead Center for International Affairs. He is currently completing a book that develops a theoretical account for why some cities are more effective than others in reducing inequality. This work compares the governance of urban public goods in Johannesburg and São Paulo after national transitions to democracy. His research articles have previously been published in Social Forces, City \& Community, International Journal of Urban and Regional Research, Environment \& Urbanization, and International Development Planning Review. 